\title{
CHILD LABORERS ACCESS TO EDUCATION IN KANDAHAR CITY
}

\author{
Salman Ali Nabavi \\ Lecturer \& Chairman \\ Geography Dep. Faculty of Education \\ Kandahar University, Kandahar, Afghanistan \\ E-mail: nabavi.edu.kdh@gmail.com \\ Alinaqi Mohammadi \\ Lecturer \\ Pedagogy \& Psychology Dep. Faculty of Education \\ Kandahar University, Kandahar, Afghanistan \\ E-mail: alinaqimohammadi2000@gmail.com \\ Jailani Achak \\ Lecturer \& Chairman \\ Chemistry Dep. Faculty of Education \\ Kandahar University, Kandahar, Afghanistan \\ E-mail: jailaniachak11@gmail.com \\ Ezatullah Sail \\ Professor \& Chairman \\ Geography Dep. Faculty of Education \\ Nangarhar University, Nangarhar, Afghanistan \\ E-mail: sailezatullah0@gmail.com
}

\begin{abstract}
This study describes the child laborers' access to education in Kandahar city. We present the methodology followed in the study, study area and type of data collected to estimate to dimensions of child laborers access to education in the city. Data collected contains information about sociodemographic characteristics, Child laborer access to education, negative impacts of working on children's education and Head of household education. It is hoped that this study would intensify a debate on main barriers to education that could tie in with analysis and commentary on providing education and related facilities to marginalized groups like child laborers and girls in society. Readers are encouraged to consider how to understand the landscape that child laborers are confronting, while also asking critical questions about the socio-political circumstances and inefficiency of educational system in which we all participate as we fight to eliminate marginalization and illiteracy in the society. Finally, it is recommended that there is a need to re-vision of the schooling system in order to evolve ways and means of offering education that is inclusive and relevant for working children in Kandahar city and other similar context.
\end{abstract}

Keywords: Child Labor, Education, Kandahar City, Afghanistan. 


\section{INTRODUCTION}

Education have a dominant impact in addressing socio-economic problems in society and is fundamental in building human capacity and empowering people. Therefore, ILO stated that education is a right, not a privilege, and should be available to everyone (ILO, 2018b). For this purpose, various agencies such as UNICEF, World Bank, IPEC-ILO and UNESCO are fighting against child labour through providing access to education to all children (Osment, 2014).

Currently numerous countries have already reached the goal of universal primary education. However, the progress in low income countries are still very slow (Osment, 2014). In this context study shows that about $94 \%$ of out-of-school children of primary school age are in developing countries, mainly in sub-Saharan Africa and south Asia (Education for All, 2007). Similarly, Understanding Children's Work (UCW, 2012) noted that about one-quarter of the world's out-of-school primary age population (15 million in total) is engaged in child labor. For example, in sub-Saharan Africa, about 10 million out-of-school children are engaged in different types of work. Household chores is not included in these estimates (Brown, 2012), and in south Asia a vast majority of 16 million out of school are engaged in child labour (Pappu \& Vasanta, 2020)

In Afghanistan, study estimates that 29\% of total children aged 5-17 years are engaged in child labor, where children below the age of 15 made up above $47 \%$ of the entire population (ILO, 2018a). Moreover, when it comes to hazardous child labour, this country has been identified as one of the most difficult countries for children (ILO, 2018a), this phenomenon is highly prevalent in its western and southwestern parts (Lutf \& Yasini, 2018).

Furthermore, based on the ALCS survey 2016-17 Afghanistan is the seventh-lowest country in the world in primary education (Mosadiq \& Kaandorp, 2018). Painfully, more than 3.5 million children or one third of Afghan children were out of school at the start of the school year in March 2017 (World Bank, 2018). More specifically, provincial analysis shows that the proportion of children out of school exceeds $50 \%$ in 15 provinces including Kandahar. In Kandahar $76 \%$ of school aged children ( $89 \%$ female and $63 \%$ male) are out of school (World Bank, 2018).

In addition, the number of children enrolled in schools is much higher than the number graduated because the number of student decreases as they reach at the working age in Afghanistan. In this context, Save the Keeley and Little (2017) estimates that every day about 1000 students are dropping out of school in Afghanistan (Mosadiq \& Kaandorp, 2018).

Kandahar city as a regional hub in southern Afghanistan, is a second large city, located in the southeastern area of the country, with about 523,259 populations (NSIA, 2021). Besides to urbanization and someway industrialization developed throughout the city, followed by ever increasing population growth mainly because of immigration of many people from various districts of Kandahar province, Urozgan, Helmand, Farah, Zabul and as well from other parts of the country (Saeedi, 2019). All of these, along with unemployment, poverty, and population structure, have resulted in poor socio-economic conditions and fueled the expansion and prevalence of many vulnerable groups (such as children) throughout the city.

Though, previous findings indicate that child labor has been increasing across the country over the past years, specifically in south western parts of Afghanistan and it further increased the number of out of school children but, there is no empirical study carried out in this context. This research attempts to empirically study child laborers access to education in Kandahar city, the negative impacts of working on children's education and Head of household education. Thus, by exploring and analyzing of the status of child laborers access to education in Kandahar city and its other related aspects, this problem shall be addressed by development of a proper strategy and programs. This will lead to improve the access of child laborers to education in Kandahar city as well as the entire country in general. 


\section{REVIEW OF LITERATURE}

Lack of education and also poor quality education is regarded as one of the main factor that cause the high occurrence of child labour (Osment, 2014). Relevant studies indicate that children who work for a significant number of hours and days are likely to drop out of school, get lower marks/grades and have irregular attendance (AIHRC, 2006; Heady, 2000; ILO 2009; ILO, 2018; ILO, 2017 \& Osment, 2014). Evidence further shows that most child laborers in school face elevated risks of dropping out before completion, grade repetition, and failure to make the transition to secondary education and the risks increase over time as children reach the higher grades (Brown, 2012). Study also illustrate that countless children combing work with school and most of them dropping out of school. For example, there are large drop outs in Bangladesh, India and Pakistan with 13 million children drop out-of-school and rising (Brown, 2012 \& Osment, 2014).

In addition, there is also evidence that learning outcomes of school children are adversely effected by child labor. For instance, studies in Pakistan and Nicaragua observed that "an additional hour per day worked by children attending school has a non-trivial influence on grade repetition and learning outcomes" (Brown, 2012). Data from eleven countries in Latin America also shows around 16\% disadvantage of test score for child laborers in language skills in third and fourth grades and also similar lose was found for math (Brown, 2012). Similarly, Emerson et al. (2017) on a study in Brazil followed the same children over time, observing the child's performance in school and labor status. They considered two children with equivalent educational backgrounds, both were in the same year and have identical performance measures. The child who starts working while still attending school does not test as well; the working child's lower test scores are equivalent to one quarter to three fifths of a year less knowledge accumulation than the child who did not start working (Edmonds, 2015).

Moreover, the household survey data shows that "there is a strong inverse relationship between household wealth and parental education on the one hand and child labor on the other the wealthier and better educated the parents, the lower the incidence of child labor" (Brown, 2012). Likewise, in Nigeria, child laborers from families where the household head has no education are almost ten times more likely to be out of school as those from families in which the household head has a secondary education (Brown, 2012).

In the same way, data shows that the future prospects for child laborers are also limited. For example, Ilahi et al. (2000) witnessed that "adults aged 18 and older who started fulltime work before age 13 have adult wages that are 13-17\% lower than adults who entered the workforce later" (Edmonds, 2008). Alike, Khan (2007) stated that children who lack education or drop out of their school, generally lack knowledge and are more vulnerable to exploitation. As a result, they become uneducated or unskilled labour.

Though, there are different reasons in addition to child labour which affects primary school enrollment like, high cost of education, parental unemployment and poor quality of teachers in low income countries affected the enrollment rates (Osment, (2014). In this regard, Akarro \& Mtweve (2011) found that "the number of primary and secondary school remains low in developing countries because millions of children are being forced to work instead of going to school".

Considering the above evidences, the dropout rate is a challenging problem for all levels of Afghan education. Students drop out of schools for different reasons like, to pursue work, avoid attack, get married, or merely become too old to attend school (Adkins, 2016). On a similar study, Mansory (2007) interviewed Afghan students and educators and surveyed 72 schools. He observed that fifty percent of male students and $26 \%$ of female students dropped out for the reason that they were needed for work at home (Adkins, 2016).

More embarrassingly, Afghan students are situated in the middle of a violent war, social casualties and political unrests. As a result, they are facing with a wide variety of challenges 
such as providing universal access, preventing drop outs, increasing enrollment for women, and attacks on schools (Adkins, 2016). In addition, a large number of school-aged children living in rural areas of the country do not have access to any organized educational programs and related facilities and also many of the existing schools do not have suitable buildings, safe drinking water, or sanitation facilities and for individuals with disabilities there no facilities at all (Trani et al., 2012).

\section{RESEARCH METHODOLOGY}

The methodology of this study uses quantitative research tools to provide experimental evidence on child laborers access to education in Kandahar city. Though, previous findings indicate that child labor has been increasing across the country over the past year, specifically in south western parts of Afghanistan, mainly due to rising unemployment and poverty but there is no empirical study carried out in this context. Meanwhile the related studies in Afghanistan have faced serious validity and reliability shortcomings, mostly because of using secondary/official data which may lacks transparency. However, to examine the status of child laborers access to education in the city; the data was collected through surveys (face-to-face) to child laborers from all the 15 districts of Kandahar city, Kandahar-Afghanistan during 2020. In absence of general census data in the country particularly in Kandahar city, we have carried out our study, considering population on the basis of simple random sampling designs.

The process of data collection involved visiting potential respondents in their districts/Children in their places of work and schools. The respondent for this study were selected based on their child laboring status, and the focal child's age (7-18) years old. Children that: (i) work full time and (ii) combine work and schooling. Within the districts, respondents were identified to participate in the survey based on our study objectives and the children were traced in their work places, on streets, workshops, shops, factories, schools and etc. In total, the questionnaires randomly administered to a sample of 212 respondents, equaling to roughly 14 in each district. For obtaining the desired information, a well-structured research instrument (questionnaire) was developed from the review of the literature, through which a sample size of 212 households has been surveyed.

Quantitative data was managed using a statistical software package. Statistical Package for the Social Sciences (SPSS) IBM24 Version was used for data entry and analysis of the data. And then through descriptive statistical analyses the frequency and percentage of the data developed and presented by the related tables.

\section{FINDINGS AND DISCUSSION}

In this section, the different proposed research questions will be addressed.

\section{Child Laborer Access to Education in Kandahar City}

Child laborers in Kandahar city face with multidimensional deprivation including deprivation from right to education, play and enjoying from their childhood. The first objective of the study is to find out the educational background of child laborers in Kandahar city. The findings are presented as in Table 1.

Table 1. Shows the educational background of child laborers in Kandahar city.

\begin{tabular}{|l|l|l|}
\hline Education level & Frequency & Percent \\
\hline Illiterate & 70 & 33 \\
\hline Primary & 52 & 24.5 \\
\hline secondary & 53 & 25.0 \\
\hline
\end{tabular}




\begin{tabular}{|l|l|l|}
\hline High school & 37 & 17.5 \\
\hline Total & 212 & 100.0 \\
\hline
\end{tabular}

Table 1 show that $33 \%$ of child laborers have never enrolled and are illiterate in Kandahar city. While $17.5 \%$ of them are in high school and the rest of them are in primary and secondary school.

Recent study also points out that in Kandahar $76 \%$ of school-aged children are out of school (World Bank, 2018). In general, data shows that about 3.7 million children aged 7-17 years are out of school in Afghanistan, of whom, 2.2 million are girls and others yet are at risk of dropping out (UNICEF, 2018b; UNICEF, 2020; World Bank, 2018).

Furthermore, evidence indicates that lack of education as well as poor quality education in Afghanistan is considered as one of the main causes of child labour, that along with family income have negative effects on children's education, as a result, children are compelled to work rather to go to school (Osment, 2014). In this context AIHRC (2006) stated that "the average annual expenditure of a student is estimated USD 150-200 (10 to 15 thousand Afs), while the annual income of a state employee (most of the working children have no parents, or their parents are jobless) is not more than USD 600-700". The report further points out that "an average family has 3 to 5 children at the school age and their education expenditure is beyond the financial capacity of parents, even if they are state employees. Additionally, in most of the families, father is the only bread earner. In cases of his death or incapability to earn expenditure, the children are automatically forced to work" (AIHRC, 2006)

Moreover, increasing insecurity and school attacks puts Afghan children progress at risk. As UNICEF (2018a) reported that "181 schools were attacked between January and September 2018, more than double the 82 schools attacked during the same period in 2017'. Furthermore, over 1,200 schools are closed due to insecurity, and about 600,000 students have been deprived of their rights to education (UNICEF, 2018a). Recent reports also pointed out that nearly 1000 schools were destroyed in last 20 years (Ahmadi, 2021).

\section{Negative Impacts of Working on Children's Education}

The second objective of the study examined the negative impacts of working on children's education in the city. The findings are presented as in Table 2.

Table 2. Negative impacts of working on children's education in Kandahar city

\begin{tabular}{|l|l|l|}
\hline Does working have negative impacts on your education? & Frequency & Percent \\
\hline yes & 126 & 59.4 \\
\hline no & 27 & 12.7 \\
\hline No idea & 59 & 27.8 \\
\hline Total & 212 & 100.0 \\
\hline
\end{tabular}

Table 2 show that $59.4 \%$ of the respondents expressed that child laboring has negative impacts on children's education, while only $12.7 \%$ of them said that working has no negative impacts on children's education. Meanwhile, a considerable number of child laborers $(27.8 \%)$ had no idea in this case.

Previous studies have also found that children who work for a large number of hours and days are likely to drop out of school, get lower marks/grades and have irregular attendance (AIHRC, 2006; Brown, 2012; Heady, 2000; ILO 2009; ILO, 2017; ILO, 2018 \& Osment, 2014). 
Specifically, evidence shows that only $43 \%$ of children and youth under the age of 24 actively attend schools in Afghanistan (World Bank, 2018). There are a large number of children who attempt to combine work and school, however, these children face many problems in attendance and performance. In these regards, respondents in a study in Herat and Kabul said that "employers did not allow children to attend school or spend time on homework, while teachers punished children who missed school or failed to complete homework due to their workload. Child respondents also reported feeling exhausted by the demands of work and school and shamed by teasing from their non-working classmates" (MacDonald, 2008).

In addition, another challenge is the dropout rate for all levels of Afghan education due to variety of reasons. Some students want to pursue work, avoid attack, get married, or become too old to go to school (Adkins, 2016). As Save the Children in March 2017 estimated that every day about 1000 students are dropping out of school in Afghanistan (Mosadiq \& Kaandorp, 2018). All these are the contributing factors that have negative impacts on working children's education and related performance.

Although children are increasingly entering school, but there is very few progress in reducing drop-out rates. Because "in a 2009 survey of 44 national education plans, only eight plans identified child laborers as a marginalized group and of these, only four plans offered specific strategies to reach them" (UNICEF, 2014). Thus, education strategies must be properly developed and applied to progressively ensure the enrolment and retention of excluded and vulnerable groups of children.

\section{Head of Household Education}

The third objective of the study considered the education characteristics of household head of child laborers in Kandahar city. The findings are presented as in Table 3.

Table 3. Education characteristics of household head of child laborers in Kandahar city

\begin{tabular}{|l|l|l|}
\hline Is the head of your family educated? & Frequency & Percent \\
\hline yes & 49 & 23.1 \\
\hline no & 163 & 76.9 \\
\hline Total & 212 & 100.0 \\
\hline
\end{tabular}

Table 3 show that $76.9 \%$ of child laborers household head in Kandahar city are illiterate; while on $23.1 \%$ of them have literacy.

Earlier studies in Afghanistan also showed that parental education and location play an important role in school enrolment and attendance decisions. For example, children of literate parents are three times more likely to attend school than children of illiterate parents ( 57 percent v. 19 percent) (World Bank, 2018 \& UNICEF, 2018b). In this regard the United Nations Educational, Scientific, and Cultural Organization Institute for Statistics (2014) reported that in Afghanistan $45 \%$ of adult men and $18 \%$ of adult women can read and write (Adkins, 2016). In fact, several studies evidenced that child laborers are more likely to be parents of child laborers themselves. In Egypt, Wahba (2006) shows that "the children of child laborers are 10 percent more likely to be child laborers themselves, holding everything else equal" (Edmonds, 2015). Additionally, the household survey data shows that "there is a strong inverse relationship between household wealth and parental education on the one hand and child labor on the other the wealthier and better educated the parents, the lower the incidence of child labor" (Brown, 2012). Likewise, in Nigeria, child laborers from families where the household head has no education are almost ten times more likely to be out of school as those from families in which the household head has a secondary education (Brown, 2012). 


\section{CONCLUSION AND RECOMMENDATIONS}

Child laborers access to education, negative impacts of working on children's education and head of household education of Child laborers in Kandahar city were investigated in this study. Similarly, earlier studies found that children whose households are in the lower three wealth quintiles, children whose head of household has no formal education and children in insecure areas are less likely to attend school. The findings of this study show that $33 \%$ of child laborers have never enrolled and are illiterate in Kandahar city. Furthermore, we found that, $59.4 \%$ of the child laborers feel that child laboring has negative impacts on children's education, in addition, $76.9 \%$ of child laborers household head in Kandahar city are unsurprisingly illiterate. We recommend that there is a need to revise the schooling system in order to evolve ways and means of offering education that is inclusive and relevant for working children in Kandahar city and other similar context. It should also be noted that the elimination of child labour, however, is not too simplistic and is unachievable in the short term specifically in Kandahar city. While there is poverty, children must work to help with their own and their families' subsistence. There has to be a multidimensional approach. One that in one hand reduces the child laboring phenomena by addressing its root causes while, on the other hand, providing a flexible education system planned to meet the child laborers needs. Some specific options to cope this problem may be listed as the following:

- Enhancing the capacity of families and communities; Creating employment opportunities and social programs to support families in need and help them find alternative income to replace their child's employment will help prevent child labor, access to education and good educational achievements.

- The government should pay meaningful attention to enhance education quality to increase family's interest in education of their children.

- The government should provide compulsory basic education for those child laborers who have not completed elementary education, through organizing special programs.

- The Ministry of Education should identify child laborers as a marginalized group and design and implement effective strategies to ensure the access child laborers to elementary education.

\section{REFERENCES}

Adkins, M. J. (2016). Challenges for Progressive Education in Afghanistan: A History of Oppression and the Rising Threat of ISIS. International Journal of Progressive Education, 12(2).

Ahmadi, H. (2021). One thousand schools have been destroyed in the last 20 years. Retrieved from https://nimrokh.af/9424/one-thousand-schools-have-been-destroyed-in-20years/

Afghan Independent Human Rights Commission (AIHRC). (2006). An Overview on Situation of Child Laborers in Afghanistan, Afghanistan Independent, a research report. 3-12. Retrieved from https://www.refworld.org/pdfid/471f4a560.pdf

Akarro, R. R., \& Mtweve, N. A. (2011). Poverty and its association with child labor in Njombe District in Tanzania: the case of Igima ward. Current Research Journal of Social Sciences, 3(3), 199-206.

Brown, G. (2012). Child Labor \& Educational Disadvantage-Breaking the Link, Building Opportunity A Review by. 
Edmonds, E. V. (2008). Defining child labour: A review of the definitions of child labour in policy research. ILO.

Emerson, P. M., Ponczek, V., \& Souza, A. P. (2017). Child labor and learning. Economic Development and Cultural Change, 65(2), 265-296.

Edmonds, E. V. (2015). Economic Growth and Child Labor in Low Income Economies. A Systhesis Paper Prepared for IZA/DFID. Bonn: Institute for the Study of Labor. google scholar

Education for All. (2007). Education for All Global Monitoring Report 2008: Education for All by 2015. Will We Make It?. Oxford University Press.

Heady, C. (2000). What Is the Effect of Child Labour on Learning Achievement? Evidence from Ghana. Innocenti Working Papers.

International Labour Organization (ILO). (2018a). Training manual on child labour in Afghanistan. ILO, 2018. https://www.ilo.org/wcmsp5/groups/public/---ed_norm/--ipec/documents/instructionalmaterial/wcms_667934.pdf

International Labour Organization (ILO). (2018b). Towards the urgent elimination of HAZARDOUS CHILD LABOUR. Available at: https://www.ilo.org/ipec/Informationresources/WCMS_IPEC_PUB_30315/lang-en/index.htm

International Labour Organization (ILO). (2009). Understanding the concept of child labour / International Labour Office, 2009. http://webcache.googleusercontent.com/search?q=cache:pUFi1J4KuT0J:www.ilo.org /ipecinfo/product/download.do\%3Ftype\%3Ddocument\%26id\%3D13993+\&cd=1\&hl $=$ fa\&ct $=$ clnk $\& \mathrm{gl}=\mathrm{af}$

Ilahi, N. (2000). The intra-household allocation of time and tasks: What have we learnt from the empirical literature?. Washington, DC: World Bank, Development Research Group/Poverty Reduction and Economic Management Network.

International Labour Organization (ILO). (2017). Global estimates of child labour: Results and trends, 2012-2016. google scholar

Khan, A. A. (2007). Stakeholders' perceptions and action for addressing students' dropout in a government secondary school in Karachi.

Keeley, B., \& Little, C. (2017). The State of the Worlds Children 2017: Children in a Digital World. UNICEF. 3 United Nations Plaza, New York, NY 10017.

Kondylis, F., \& Manacorda, M. (2006). School proximity and child labor evidence from rural Tanzania. Retrieved from https://personal.lse.ac.uk/manacorm/dist_to_school.pdf

Lutf, L., \& Yasini, S. I. H. (2018). Factors Contributing to Child Labor in Afghanistan: A Case Study in Jalalabad City. Economic Alternatives, (3), 348-372. 
Mansory, A. (2007). Drop out study in basic education level of schools in Afghanistan. Kabul: Swedish committee for Afghanistan.

MacDonald, D. (2008). Afghanistan research and evaluation unit briefing paper series: Afghanistan's hidden drug problem: the misuse of psychotropics. Kabul: Afghanistan Research and Evaluation Unit.

Mosadiq, H., \& Kaandorp, M. (2018). Child Notice Afghanistan. Produced by UNICEF The Netherlands, in cooperation with UNICEF Afghanistan.

National Statistics and Information Authority (NSIA). (2021). Retrieved from https://nsia.gov.af/home

Osment, L. (2014). Child labour; the effect on child, causes and remedies to the revolving menace.

Pappu, R., \& Vasanta, D. (2020). Child labor and education in South Asia. Handbook of education systems in South Asia, 1-26.

Saeedi, K. H. (2019). Municipal solid waste management analysis in Kandahar city. Octa Journal of Environmental Research, 7(1), 010-018.

Trani, J. F., Bakhshi, P., \& Nandipati, A. (2012). Delivering'education; maintaining inequality. The case of children with disabilities in Afghanistan. Cambridge Journal of Education, 42(3), 345-365.

UNICEF. (2019). Nine Afghan children killed or maimed daily in world's most lethal warzone - UNICEF. Press release 16 December 2019. Retrieved from https://www.unicef.org/afghanistan/press-releases/nine-afghan-children-killed-ormaimed-daily-worlds-most-lethal-warzone-unicef

UNICEF. (2018a). Geneva Palais briefing note on the situation of children in Afghanistan. UNICEF. Press release, 27 November 2018. Retrieved from https://www.unicef.org/afghanistan/press-releases/geneva-palais-briefing-notesituation-children-afghanistan

UNICEF. (2018b). GLOBAL INITIATIVE ON OUT-OF-SCHOOL CHILDREN; AFGHANISTAN COUNTRY STUDY. Ministry of Education, Islamic Republic of Afghanistan, and United Nations Children's Fund (UNICEF) 2018. Retrieved from https://www.unicef.org/afghanistan/sites/unicef.org.afghanistan/files/2018-05/afgreport-oocs2018.pdf

UNICEF. (2021). Child protection; Protecting Afghanistan's most vulnerable children. Programme. Retrieved from https://www.unicef.org/afghanistan/child-protection

UNICEF. (2020). Education; Providing quality education for all. Programme. Retrieved from https://www.unicef.org/afghanistan/education

UNICEF. (2014). Child labour and UNICEF in action: children at the centre. New York: UNICEF. 
UCW. (2012). Understanding children's work and youth employment outcomes in Indonesia. Rome, Understanding Children's Work (UCW) Programme

World Bank. (2018). Afghanistan: Promoting Education during Times of Increased Fragility. World Bank.

Wahba, J. (2006). The influence of market wages and parental history on child labour and schooling in Egypt. Journal of Population Economics, 19(4), 823-852.

\section{Copyrights}

Copyright for this article is retained by the author(s), with first publication rights granted to the journal. This is an open-access article distributed under the terms and conditions of the Creative Commons Attribution license (http://creativecommons.org/licenses/by/4.0) 